\title{
Selected dried fruits as a source of nutrients
}

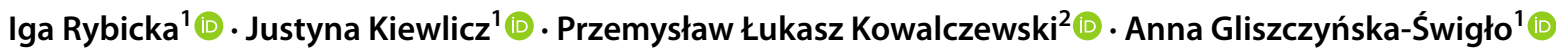

Received: 17 January 2021 / Revised: 16 June 2021 / Accepted: 19 June 2021 / Published online: 30 June 2021

(c) The Author(s) 2021

\begin{abstract}
Dried fruits are an excellent alternative to unhealthy snacks. Twelve commercially available dried fruits were selected: dates, raisins, prunes, Goji berry, chokeberry, rose hip, sea buckthorn, berberis, physalis, haritaki, noni and juniper. The nutritional value in terms of moisture, ash, protein, fat, carbohydrate, dietary fiber, energy value, mineral composition, antioxidant activity and tannins was compared. It is a novelty in the literature in relation to the particular analytes (e.g., minerals, tannins) and/or fruits (e.g., berberis, noni, haritaki). Especially rich in protein were Goji berry (13.3\%), sea buckthorn (9.3\%), noni (8.9\%) and physalis (8.0\%); in fat - sea buckthorn (11.2\%); in dietary fiber (4.4-53.0\%) - most of analyzed products. High antioxidant capacity was noticed for haritaki, berberis, rose hip, Goji berry, and physalis. An important source of minerals was $100 \mathrm{~g}$ of: noni (345 mg of $\mathrm{Ca} ; 251 \mathrm{mg}$ of $\mathrm{Mg}$ ), rose hip (844 mg of Ca; $207 \mathrm{mg}$ of $\mathrm{Mg}$ ), juniper (564 mg of Ca), sea buckthorn ( $58 \mathrm{mg}$ of $\mathrm{Fe}$ ), berberis ( $24 \mathrm{mg}$ of $\mathrm{Fe}$ ) and haritaki ( $14 \mathrm{mg}$ of Fe). The nutritionally attractive dried fruits have the potential for wider application in food formulations.
\end{abstract}

Keywords Dietary fiber $\cdot$ Dried fruit $\cdot$ Mineral $\cdot$ Nutritional value

\section{Introduction}

Fruits are an integral and important part of everyday diet. Most of the food-based dietary guidelines (FBDG) in the world recommend consuming 5 portions (approx. $400-500 \mathrm{~g}$ ) of fruits and vegetables a day [1]. It is also suggested to choose seasonal fruits that are available in a particular region but a significant difficulty in the implementation of these recommendations is the limited availability of fresh fruits throughout the year. Therefore, dried fruits are an alternative to fresh fruits but to a limited extent. On the one hand, most of them can be characterized as rich in dietary fiber and antioxidants, on the other hand, by a high content of sugars, mainly fructose, and moderate to high energy value [2]. Sullivan and co-authors [3] analyzed the impact of dried fruits consumption on the nutrients intake

Iga Rybicka

iga.rybicka@ue.poznan.pl

1 Institute of Quality Science, Poznań University of Economics and Business, al. Niepodległości 10, 61-875 Poznań, Poland

2 Department of Food Technology of Plant Origin, Poznań University of Life Sciences, 31 Wojska Polskiego St, 60-624 Poznań, Poland among participants of the National Health and Nutrition Examination Survey in the United States between 2007 and 2016. They concluded that higher consumption of dried fruits can increase the intake of under-consumed nutrients such as dietary fiber and potassium, but it can also lead to higher energy intake. Therefore, FBDG in some countries precisely suggests the consumption of two to three portions (40-60 g) of dried fruits a week [4].

Dried fruits can be easily prepared on our own and, more often, can be bought almost everywhere. In 2018, 28\% of dried fruit consumption was accounted for Middle-East, $27 \%$ for Europe, 24\% for Asia, 13\% for North America and 8\% for other regions [5] The world production of dried fruit raised from 2.3 million metric tons in 2009/2010 to 3.2 million metric tons in 2019/2020 led by United States (16\% of production share), Turkey (15\%), Iran (12\%) and Saudi Arabia (7\%) [5]. The most popular dried fruits in the world are raisins, almost half of the worldwide production, and then dates, prunes, figs, apricots, peaches, apples, and pears. For some regions, dried fruits are an important element of the economy [6] but, in general, their popularity is still limited. In Poland, $7.1 \%$ of expenditures for food were spent on fruits and only $1.2 \%$ for dried fruits, frozen fruits, nuts, and fruit preserves. The study conducted by Jesionkowska et al. [7] among Dutch, French and Polish consumers showed that 
products with the addition of dried fruits (e.g., oatmeal) are much more popular than dried fruits themselves but even in this form they are consumed a few times a month.

Some fruits such as blueberries or cherries were treated with sweetener, others, such as raisins, were mixed with oil before drying. It was to improve the taste and overall attractiveness of the product. Nowadays, consumers search for e.g., 'clean-label' and 'free-from" products so most of the producers avoid adding sugar, preservatives, oil or other ingredients [8]. These trends have driven the food industry towards nutritious, wholesome and minimally processed food products and their consumption are forecasted to grow in the upcoming years. Only in the last decade the production of dried fruit worldwide has increased from 2,25 mln metric tons in 2009/2010 to 3,22 mln in 2019/2020 [5].

Dried fruits perfectly fit into current 'natural' nutritional trends but the data on the less popular dried fruits are very limited. Therefore, the aim of the study was to assess the nutritional quality of selected commercially available dried fruits. These were popular fruits such as dates, raisins and prunes, and less popular like Goji berry, chokeberry, rose hip, sea buckthorn, physalis or almost unknown: berberis, haritaki, noni and juniper. Some of them are called "superfruits" because of their extraordinary health benefits. The paper describes nutritional and antinutritional composition including energy value, carbohydrates, fat, protein, dietary fiber, minerals, tannins and antioxidant activity. It is a novelty in the literature for most of products analyzed and consist a basis for the potential use of, formerly unknown, dried fruits in food products such as oatmeal or bars.

\section{Material and methods}

\section{Materials}

Twelve dried fruits were purchased in a Polish on-line shop in 2019. These were: dates (Phoenix dactylifera), raisins (Vitis vinifera), prunes (Prunus domestica), Goji berry (Lycium barbarum), chokeberry (Photinia melanocarpa), rose hip (Rosa canina), sea buckthorn (Hippophae rhamnoides), berberis (Berberis vulgaris L.), physalis (Physalis peruviana), haritaki (Terminalia chebula), noni (Morinda citrifolia) and juniper (Juniperus communis). All analyzed products were purchased from the same company (NatVita, Mirków, Poland) and, did not contain any additives (except for oil in raisins). The photography and description (including ingredients, Latin systematic name and country of origin) based on the producer's declaration were presented in Table 1.

\section{Proximate composition}

All samples were frozen at $-85^{\circ} \mathrm{C}$ and freeze-dried. The freeze-drying process was performed using Alpha 2-4 LD plus lyophilizer (Martin Christ, Osterode am Harz, Germany). Samples were milled using a M 20 Universal mill (IKA ${ }^{\circledR}$-Werke GmbH \& CO. KG, Staufen, Germany) (the stone was removed from haritaki). All further analyses (excluding moisture) were performed on dried samples.

The total nitrogen was determined by the Kjeldahl method according to ISO 20,483 (ISO, 2013) and was used to calculate the protein content by multiplying the result by the conversion factor of 6.25 . The ash content was determined according to ISO 2171 (ISO, 2007) and the total fat content was determined according to AACC 30-25.01 (AACC, 2009). Measurement of moisture content was performed according to AACC 44-19.01 (AACC, 2009). The total dietary fiber (TDF) was isolated according to AOAC enzymatic-gravimetric methods (AOAC 991.42; AOAC 993.19). $1 \mathrm{~g}$ of the sample was dispersed in $50 \mathrm{~mL}$ of phosphate buffer $(\mathrm{pH} 6.0 \pm 0.2)$ and incubated with $50 \mu \mathrm{L}$ of $\alpha$-amylase for $30 \mathrm{~min}$ at $95-100{ }^{\circ} \mathrm{C}$. After cooling, the $\mathrm{pH}$ was adjusted to $7.5 \pm 0.1$ and $100 \mu \mathrm{L}$ of protease was added. The sample was kept at $60{ }^{\circ} \mathrm{C}$ for $30 \mathrm{~min}$. Hot solution was set to $\mathrm{pH}$ of 4.0-4.6 and $200 \mu \mathrm{L}$ of amyloglucosidase was added and was kept at $60^{\circ} \mathrm{C}$ for another $30 \mathrm{~min}$. The residue obtained was filtered under reduced pressure (Fibertec 1023 system, Foss, Copenhagen, Denmark), washed with solvents (ethanol and acetone) and dried as insoluble dietary fiber (IDF) at $105^{\circ} \mathrm{C}$ to constant weight. The filtrate was collected, ethanol $\left(95 \%, 60^{\circ} \mathrm{C}\right)$ was added and the solution was left for $1 \mathrm{~h}$ to precipitate soluble dietary fiber (SDF). The ratio of ethanol to sample volume was 4:1. The obtained fraction was filtered under reduced pressure, washed with solvents and dried at $105^{\circ} \mathrm{C}$ to constant weight. TDF was calculated as the sum of IDF, SDF, ash and non-digestible protein. Non-digestible protein was determined by the Kjeldahl method (AOAC 2001.11). The determination of ash was analyzed by ignition at $525^{\circ} \mathrm{C}$ for $5 \mathrm{~h}$. Blank assays were conducted in parallel and each sample was analyzed in triplicate. The carbohydrate content was estimated by subtracting the total ash, fat, dietary fiber, protein, and moisture content from $100 \%$. Moreover, the energy value was calculated with the following formula [9]:

$$
\begin{aligned}
& \text { ENERGY }[\mathrm{kcal} / 100 \mathrm{~g}] \\
& \quad=4 \times(\text { PROTEIN }+ \text { CARBOHYDRATE }) \\
& \quad+9 \times \text { FAT }+2 \times T D F
\end{aligned}
$$




\section{Tannins}

Tannins were determined according to the method by Mohapatra and co-authors [10]. $0.05 \mathrm{~g}$ of the sample was mixed with $5 \mathrm{~mL}$ of demineralized water and boiled for $30 \mathrm{~min}$. After cooling, $1.5 \mathrm{~mL}$ of supernatant was centrifuged for $10 \mathrm{~min}$ at $13,000 \times \mathrm{g}$. Subsequently, $0.5 \mathrm{~mL}$ of $20 \% \mathrm{Na}_{2} \mathrm{CO}_{3}$ and $0.25 \mathrm{~mL}$ of Folin-Ciocalteu reagent were added to $0.05 \mathrm{~mL}$ of supernatant and filled up to $5 \mathrm{~mL}$ with water. The solution was left in the dark for $30 \mathrm{~min}$ and the absorbance was measured at $700 \mathrm{~nm}$. The standard curves of tannic acid were prepared for concentrations of $0-100 \mathrm{mg} \mathrm{L}^{-1}$.

\section{Minerals}

$0.5 \mathrm{~g}$ of the sample was weighted into vessel and $7 \mathrm{~mL}$ of $\mathrm{HNO}_{3}(65 \%)$ and $1 \mathrm{~mL}$ of $\mathrm{H}_{2} \mathrm{O}_{2}(30 \%)$ were added [11]. The mineralization was carried out according to the recommendations of the manufacturer of the microwave oven: $210^{\circ} \mathrm{C}$, ramp time $-15 \mathrm{~min}$, hold time $-15 \mathrm{~min}$, pressure $-800 \mathrm{psi}$ and power-900-1050 W (CEM 6, Mars, CEM Corporation, Matthews, NC, United States). After cooling, digests were fulfilled to $50 \mathrm{~mL}$ with demineralized water (Hydrolab System, Wiślina, Poland).

The content of most minerals $-\mathrm{Ca}, \mathrm{Cu}, \mathrm{Fe}, \mathrm{K}, \mathrm{Mg}, \mathrm{Mn}$, and $\mathrm{Na}$ were determined using microwave plasma-atomic
Table 1 The characteristics of dry fruits (photography, name, origin, nutritional value)

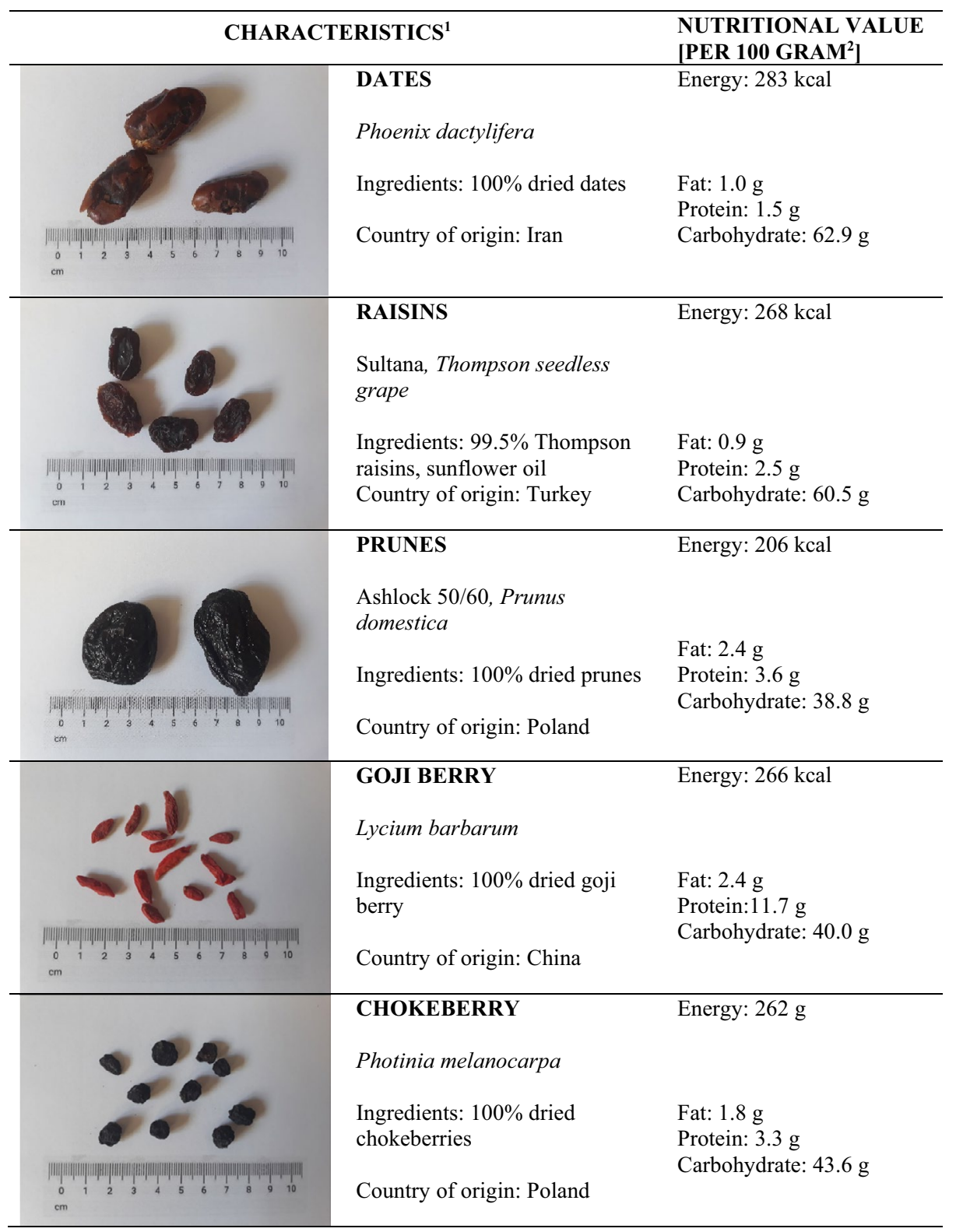


Table 1 (continued)

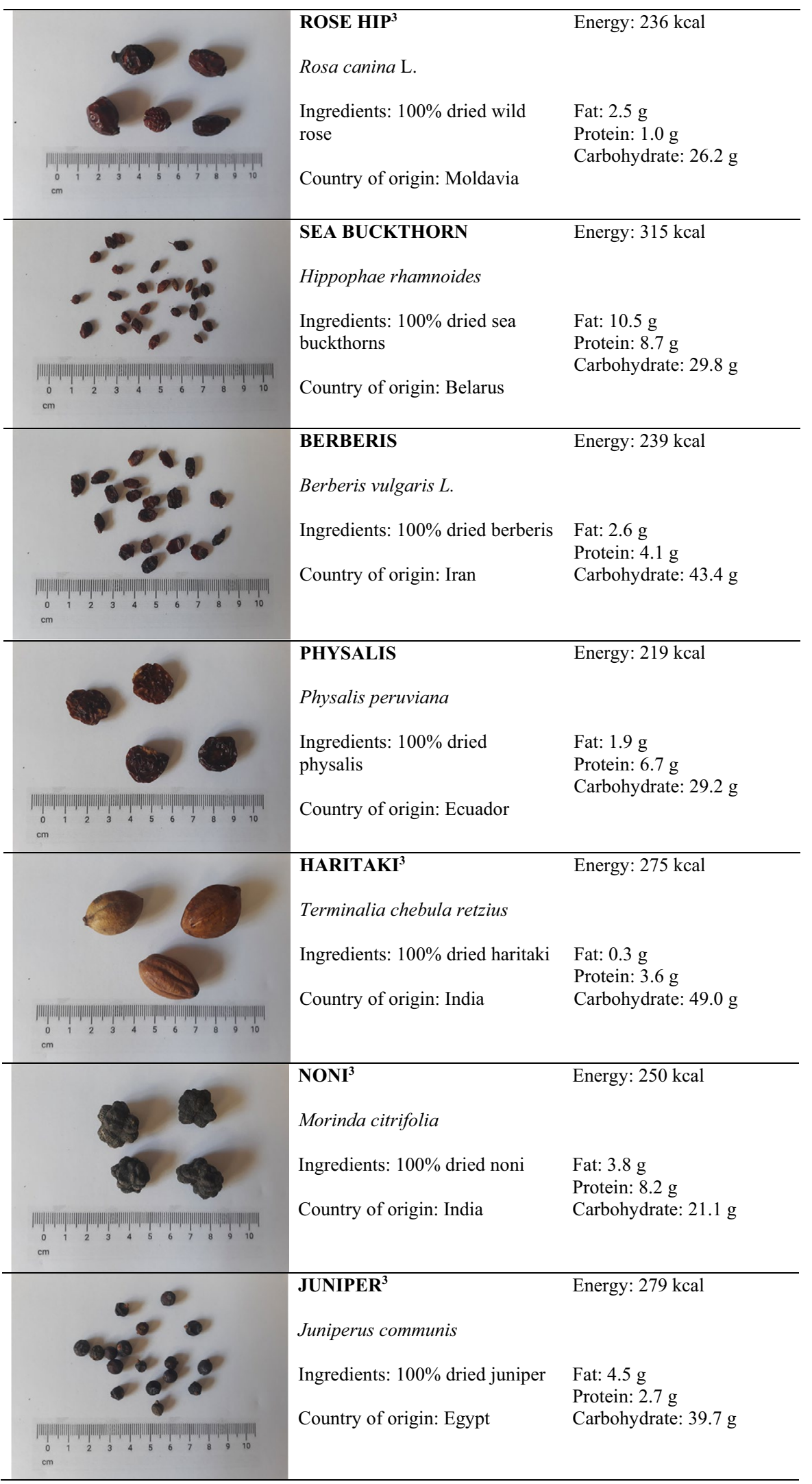

${ }^{1}$ Data from the product label

${ }^{2}$ Data from the determinations (presented for fresh matter)

${ }^{3}$ Requires milling before consumption 
emission spectrometry (MP-AES 4210, Agilent Technologies, Melbourne, Australia) according to the method described by Kiewlicz \& Rybicka [12]. For each determination, at least two calibration curves were prepared, each adjusted to the concentration in the sample analyzed. The content of $\mathrm{P}$ was determined using the spectrophotometric molybdenum blue method [13] adopted to multiply analysis. The analysis was performed in 48-microwell plates (Nunclon Delta Surface, Thermo Fisher Scientific, Roskilde, Demark) using BioTek PowerWave XS2 microplate spectrophotometer (Biokom, Warsaw, Poland).

\section{Antioxidant activity}

\section{Preparation of polyphenol extracts}

$0.05-0.2 \mathrm{~g}$ of sample was mixed with $5 \mathrm{~mL}$ of demineralized water and sonicated for 30 min using an ultrasonic bath (Sonorex RK 100, Bandelin electronic GmbH \& Co., Berlin). Extracts were filtered and kept at $-18^{\circ} \mathrm{C}$ until analysis. Two independent extractions were performed for each fruit sample.

\section{Determination of total phenolic (TP) content}

Determination of TPC in fruits was performed according to the method of Singleton and Rossi [14]. Briefly, $0.005 \mathrm{~mL}$ of fruit extract were mixed with $0.05 \mathrm{~mL}$ of Folin-Ciocalteu reagent. After $3 \mathrm{~min}, 0.15 \mathrm{~mL}$ of $20 \% \mathrm{Na}_{2} \mathrm{CO}_{3}$ and the next $0.795 \mathrm{~mL}$ of demineralized water were added. The plate was left in the dark at room temperature for $2 \mathrm{~h}$ and then the absorbance at $765 \mathrm{~nm}$ was measured using a PowerWave XS2 microplate spectrophotometer (BioTek). At least four determinations were performed for each independent extract of the fruit. The TP content was expressed as mg of gallic acid equivalents per $100 \mathrm{~g}$ of fruit (mg GAE/100 g d.m.) using the calibration curve.

\section{Determination of total flavonoid (TF) content}

Determination of TFC was performed by the spectrophotometric method with $\mathrm{AgCl}_{3}$ [15] and adapted to 48-well microplates. In brief, 0.01 or $0.05 \mathrm{~mL}$ of fruit extract were mixed with $0.5 \mathrm{~mL}$ of demineralized water, and $0.03 \mathrm{~mL}$ of $5 \% \mathrm{NaNO}_{2}$. After $5 \mathrm{~min}, 0.06 \mathrm{~mL}$ of $10 \% \mathrm{AgCl}_{3}$ and $0.2 \mathrm{~mL}$ of $1 \mathrm{M} \mathrm{NaOH}$ were added. After the next $5 \mathrm{~min}, 0.2 \mathrm{~mL}$ or $0.16 \mathrm{~mL}$ of demineralized water were added (total volume of $1 \mathrm{~mL}$ ), plate was shaken and the absorbance was measured at $510 \mathrm{~nm}$ using a PowerWave XS2 microplate spectrophotometer (BioTek). At least four determinations were performed for each independent extract of the fruit. The TF content was expressed as $\mathrm{mg}$ of $( \pm)$-catechin equivalents per $100 \mathrm{~g}$ of fruit (mg CE/100 g d.m.) using the calibration curve.
Determination of the total antioxidant capacity as the TEAC value

The total antioxidant capacity of fruits was determined using the Trolox Equivalent Antioxidant Capacity (TEAC) assay with $\mathrm{ABTS}^{\bullet+}$ radical cation according to Re et. al. [16]. ABTS $^{\bullet+}$ radical cation was generated by a reaction of $0.0077 \mathrm{~g}$ of ABTS dissolved in $1.8 \mathrm{~mL}$ of demineralized water with $0.2 \mathrm{~mL}$ of $0.0066 \mathrm{~g} / \mathrm{mL}$ potassium persulphate. The reaction mixture was incubated in the dark at room temperature for $16 \mathrm{~h}$. The $\mathrm{ABTS}^{+}$radical cation working solution was obtained by dilution with methanol to an absorbance of about 0.80 at $734 \mathrm{~nm}$. The absorbance was measured 6 min after mixing $0.008 \mathrm{~mL}$ of the sample with $0.792 \mathrm{~mL}$ of the $\mathrm{ABTS}^{+}$radical cation working solution. The TEAC value was calculated as the ratio of the linear regression coefficient of the calibration curve for five dilutions of the sample and the linear regression coefficient of the Trolox standard curve [17]. Two independent determinations were performed for each extract (four determinations for each fruit sample). The activity of fruits was expressed as the TEAC value (mmol of Trolox/100 g d.m.).

\section{Determination of the total antioxidant capacity as the FRAP value}

The FRAP (Ferric Reducing Ability of Plasma or Ferric Reducing Antioxidant Power) assay was carried out using the method of Benzie and Strain [18] with modifications described by Enko and Gliszczyńska-Świgło [17]. A volume of $0.008 \mathrm{~mL}$ of sample was added to $0.792 \mathrm{~mL}$ of the $10 \mathrm{mM}$ ferric-TPTZ reagent and the increase in absorbance at $593 \mathrm{~nm}$ was measured after $8 \mathrm{~min}$. The FRAP value was calculated as the ratio of the linear regression coefficient of the calibration curve for five dilutions of the sample and the linear regression coefficient of the $\mathrm{FeSO}_{4} \times 7 \mathrm{H}_{2} \mathrm{O}$ standard curve. Two independent determinations were performed for each extract (four determinations for each fruit sample). Activity of fruits was expressed as the FRAP value (mmol of $\mathrm{Fe}^{2+} / 100 \mathrm{~g}$ d.m.).

\section{Statistical analysis}

All results are presented as a mean \pm standard deviation. Statistical analyses were carried out using Statistica 12.0 software (StatSoft, Inc. 2013). All data were submitted to one-way analysis of variance (ANOVA). The significance of differences between mean values obtained for products was determined by the least significant differences test (LSD) at $\alpha=0.05$. 
Table 2 The proximate composition (moisture, protein, fat, carbohydrates and energy value) of dried fruits

\begin{tabular}{lccccc}
\hline Product & $\begin{array}{l}\text { Moisture [g/100 g } \\
\text { f.m. }{ }^{1} \text { ] }\end{array}$ & Protein [g/100 g d.m. $\left.{ }^{2}\right]$ & Fat [g/100 g d.m.] & $\begin{array}{l}\text { Carbohydrate }^{3} \\
{[\mathrm{~g} / 100 \mathrm{~g} \mathrm{~d} . \mathrm{m} .]^{3}}\end{array}$ & $\begin{array}{l}\text { Energy value }^{4} \\
{[\mathrm{kcal} / 100 \mathrm{~g} \mathrm{~d} . \mathrm{m} .]^{2}}\end{array}$ \\
\hline Dates & $13.0 \pm 0.2^{\mathrm{f}}$ & $1.8 \pm 0.1^{\mathrm{b}}$ & $1.1 \pm 0.1^{\mathrm{b}}$ & $72.3 \pm 4.3^{\mathrm{f}}$ & 326 \\
Raisins & $16.6 \pm 0.2^{\mathrm{h}}$ & $3.1 \pm 0.1^{\mathrm{c}}$ & $1.1 \pm 0.1^{\mathrm{b}}$ & $72.5 \pm 3.4^{\mathrm{f}}$ & 321 \\
Prunes & $25.9 \pm 0.1^{\mathrm{j}}$ & $4.8 \pm 0.4^{\mathrm{e}}$ & $3.2 \pm 0.2^{\mathrm{e}}$ & $52.3 \pm 2.9^{\mathrm{e}}$ & 279 \\
Goji Berry & $12.0 \pm 0.3^{\mathrm{e}}$ & $13.3 \pm 0.6^{\mathrm{h}}$ & $2.8 \pm 0.2^{\mathrm{de}}$ & $45.4 \pm 2.8^{\mathrm{d}}$ & 302 \\
Chokeberry & $10.3 \pm 0.1^{\mathrm{d}}$ & $3.7 \pm 0.1^{\mathrm{d}}$ & $2.0 \pm 0.1^{\mathrm{c}}$ & $48.6 \pm 2.8^{\mathrm{de}}$ & 292 \\
Rose Hip & $7.3 \pm 0.2^{\mathrm{bc}}$ & $1.0 \pm 0.1^{\mathrm{a}}$ & $2.7 \pm 0.3^{\mathrm{cde}}$ & $28.3 \pm 1.9^{\mathrm{b}}$ & 254 \\
Sea Buckthorn & $6.5 \pm 0.1^{\mathrm{a}}$ & $9.3 \pm 0.4^{\mathrm{g}}$ & $11.2 \pm 1.0^{\mathrm{h}}$ & $31.9 \pm 3.3^{\mathrm{bc}}$ & 337 \\
Berberis & $18.6 \pm 0.2^{\mathrm{i}}$ & $5.0 \pm 0.3^{\mathrm{e}}$ & $3.2 \pm 0.2^{\mathrm{e}}$ & $53.4 \pm 2.9^{\mathrm{e}}$ & 294 \\
Physalis & $15.4 \pm 0.1^{\mathrm{g}}$ & $8.0 \pm 0.3^{\mathrm{f}}$ & $2.2 \pm 0.3^{\mathrm{cd}}$ & $34.5 \pm 2.9^{\mathrm{c}}$ & 259 \\
Haritaki & $7.1 \pm 0.1^{\mathrm{b}}$ & $3.9 \pm 0.2^{\mathrm{d}}$ & $0.34 \pm 0.04^{\mathrm{a}}$ & $52.7 \pm 2.3^{\mathrm{e}}$ & 296 \\
Noni & $7.1 \pm 0.1^{\mathrm{b}}$ & $8.9 \pm 0.4^{\mathrm{fg}}$ & $4.1 \pm 0.2^{\mathrm{f}}$ & $22.7 \pm 1.9^{\mathrm{a}}$ & 270 \\
Juniper & $8.0 \pm 0.3^{\mathrm{c}}$ & $2.9 \pm 0.1^{\mathrm{c}}$ & $4.8 \pm 0.3^{\mathrm{g}}$ & $43.1 \pm 2.7^{\mathrm{d}}$ & 303 \\
\hline
\end{tabular}

${ }^{1} f . m$. fresh matter

${ }^{2}$ d.m. dry matter

${ }^{3}$ The carbohydrate content was estimated by subtracting fat, total dietary fibre, ash (presented in Table 3), protein and moisture content from $100 \%$

${ }^{4}$ Energy value was calculated based on average protein, fat and carbohydrate content three determinations for each dried fruit were performed; Mean values with the same letter in each column were not significantly different at $\alpha=0.05$ (sorted from the lowest to highest values)

\section{Results and discussion}

In the study, twelve popular and less popular dried fruits were selected. In European societies, the most popular and well described in the literature are dates, raisins, and prunes. Less popular dried fruits are e.g., Goji berry, chokeberry, rose hip, sea buckthorn, berberis, physalis, haritaki, noni and juniper. In Table 1 the detailed description of analyzed samples was presented and it included systematic name, country of origin and ingredients (if applicable). The proximate composition including the content of fat, protein, carbohydrates, and energy value was also presented in Table 1 and the data were expressed per $100 \mathrm{~g}$ of the edible portion (fresh matter) while the results presented in Tables 2, 3, 4, 5 were shown and discussed in relation to dry matter. It is worth underlining the significant differences between the moisture of analyzed products and therefore the content of nutrients and antinutrients in their edible portions. The water content in analyzed fruits was within a wide range of $7 \%$ (rose hip, sea buckthorn, haritaki, noni, juniper) and 26\% (prunes).

The content of all analyzed (protein, fat) and calculated (carbohydrates and energy value) nutrients significantly differed between selected dried fruits (Table 2). The Goji berry under the study had a high content of protein (13.3\%) which is more than presented by e.g. Rodrigues and coauthors [19] - 4-7.7\% but similar to USDA [21] - 14.3\%. Rich in protein were also sea buckthorn, noni and physalis $(8-9 \%)$, but other fruits had $5 \%$ or less protein. The content of fat was below $3 \%$ in most of analyzed products and $4-5 \%$ in noni and juniper. Much higher fat content $(11.2 \%)$ was only in sea buckthorn and resulted from the high content of fat, both in seeds and softer parts of fruit, which is highly appreciated in cosmetics [20]. The content of carbohydrates was estimated by subtracting protein, fat, dietary fiber and ash (Table 3). The lowest content of carbohydrates was calculated for noni and rose hip (below 30\%) and resulted mainly from the high content of dietary fiber. The highest content of carbohydrates (more than $70 \%$ ) was found in dates and raisins, which is in line with the existing data [21]. The energy value was between $254 \mathrm{kcal}$ (rose hip) and $337 \mathrm{kcal} / 100 \mathrm{~g}$ (sea buckthorn). For most of analyzed products the energy value was about 270-320 kcal/100 g (raisins, Goji berry, chokeberry, haritaki, noni, juniper).

The content of ash, total dietary fiber (TDF), insoluble dietary fiber (IDF) and soluble dietary fiber (SDF) was presented in Table 3 . The content of total dietary fiber (TDF) significantly differed between analyzed fruits. The lowest content was found in raisins $(4.4 \mathrm{~g} / 100 \mathrm{~g})$, average in dates, prunes, Goji berry and berberis (10-21 g/100 g), high in chokeberry, sea buckthorn, physalis, haritaki, juniper $(30-38 \mathrm{~g} / 100 \mathrm{~g})$ and very high in rose hip and noni $(53-56 \mathrm{~g} / 100 \mathrm{~g})$. The content of TDF in products under the study was similar to existing data on the dietary fiber in raisins, dates, prunes, buckthorn, Goji berry, chokeberry, physalis and rose hip [e.g. 23-25]. No data were found for dietary fiber in berberis, haritaki, juniper or noni. A large 
Table 3 The content of ash, total dietary fiber, insoluble dietary fiber, soluble dietary fiber and tannins in dried fruits

\begin{tabular}{|c|c|c|c|c|c|}
\hline Product & Ash [g/100 g d.m. $\left.{ }^{1}\right]$ & $\mathrm{TDF}^{2}$ [g/100 g d.m.] & $\mathrm{IDF}^{3}$ [g/100 g d.m.] & $\mathrm{SDF}^{4}$ [g/100 g d.m.] & $\begin{array}{l}\text { Tannins [mmol } \\
\text { TA/100 g d.m.] }\end{array}$ \\
\hline Dates & $2.1 \pm 0.1^{\mathrm{a}}$ & $9.7 \pm 0.3^{\mathrm{b}}$ & $9.2 \pm 0.3^{\mathrm{c}}$ & $0.57 \pm 0.03^{\mathrm{a}}$ & $0.72 \pm 0.02^{\mathrm{c}}$ \\
\hline Raisins & $2.3 \pm 0.1^{\mathrm{ab}}$ & $4.4 \pm 0.3^{\mathrm{a}}$ & $3.6 \pm 0.3^{\mathrm{a}}$ & $0.84 \pm 0.05^{\mathrm{b}}$ & $1.7 \pm 0.0^{\mathrm{f}}$ \\
\hline Prunes & $3.0 \pm 0.1^{\mathrm{c}}$ & $10.7 \pm 0.5^{\mathrm{b}}$ & $5.8 \pm 0.1^{\mathrm{b}}$ & $4.9 \pm 0.6^{\mathrm{f}}$ & $1.4 \pm 0.1^{\mathrm{de}}$ \\
\hline Goji Berry & $5.4 \pm 0.0^{f}$ & $21.1 \pm 1.5^{\mathrm{d}}$ & $17.4 \pm 1.9^{\mathrm{e}}$ & $3.7 \pm 0.4^{\mathrm{de}}$ & $2.8 \pm 0.1^{\mathrm{g}}$ \\
\hline Chokeberry & $3.1 \pm 0.1^{\mathrm{c}}$ & $32.2 \pm 0.5^{\mathrm{e}}$ & $30.8 \pm 0.6^{\mathrm{f}}$ & $1.5 \pm 0.1^{\mathrm{c}}$ & $1.2 \pm 0.0^{\mathrm{d}}$ \\
\hline Rose Hip & $4.3 \pm 0.1^{\mathrm{e}}$ & $56.3 \pm 0.3^{\mathrm{i}}$ & $44.3 \pm 0.3^{\mathrm{h}}$ & $12.0 \pm 0.6^{\mathrm{g}}$ & $3.2 \pm 0.1^{\mathrm{h}}$ \\
\hline Sea Buckthorn & $5.3 \pm 0.1^{f}$ & $35.8 \pm 1.4^{\mathrm{fg}}$ & $32.8 \pm 1.5^{\mathrm{f}}$ & $3.0 \pm 0.2^{\mathrm{d}}$ & $0.27 \pm 0.01^{\mathrm{a}}$ \\
\hline Berberis & $3.8 \pm 0.1^{\mathrm{d}}$ & $16.1 \pm 0.3^{c}$ & $12.5 \pm 0.8^{\mathrm{d}}$ & $3.6 \pm 0.5^{\mathrm{de}}$ & $3.8 \pm 0.1^{\mathrm{i}}$ \\
\hline Physalis & $5.5 \pm 0.2^{f}$ & $34.4 \pm 0.3^{\text {ef }}$ & $30.5 \pm 0.7^{f}$ & $3.9 \pm 0.4^{\mathrm{de}}$ & $2.0 \pm 0.2^{\mathrm{f}}$ \\
\hline Haritaki & $2.6 \pm 0.1^{\mathrm{b}}$ & $33.4 \pm 1.5^{\mathrm{ef}}$ & $32.8 \pm 1.6^{\mathrm{f}}$ & $0.56 \pm 0.1^{\mathrm{a}}$ & $11.0 \pm 0.1^{\mathrm{j}}$ \\
\hline Noni & $4.2 \pm 0.1^{\mathrm{e}}$ & $53.0 \pm 1.6^{\mathrm{h}}$ & $49.0 \pm 1.6^{\mathrm{i}}$ & $4.0 \pm 0.4^{\mathrm{e}}$ & $0.47 \pm 0.01^{\mathrm{b}}$ \\
\hline Juniper & $3.5 \pm 0.1^{\mathrm{d}}$ & $37.6 \pm 0.9^{g}$ & $35.8 \pm 0.7^{\mathrm{g}}$ & $1.8 \pm 0.2^{\mathrm{c}}$ & $1.5 \pm 0.0^{\mathrm{e}}$ \\
\hline
\end{tabular}

${ }^{1}$ d.m. dry matter

${ }^{2} T D F$ Total Dietary Fiber

${ }^{3} I D F$ Insoluble Dietary Fiber

${ }^{4} S D F$ Soluble Dietary Fiber

Three determinations for each dried fruit were performed; Mean values with the same letter in each column were not significantly different at $\alpha=0.05$ (sorted from the lowest to highest values)

Table 4 The minerals - $\mathrm{Ca}, \mathrm{Cu}, \mathrm{Fe}, \mathrm{K}, \mathrm{Mg}, \mathrm{Mn}, \mathrm{Na}, \mathrm{P}$ in dried fruits

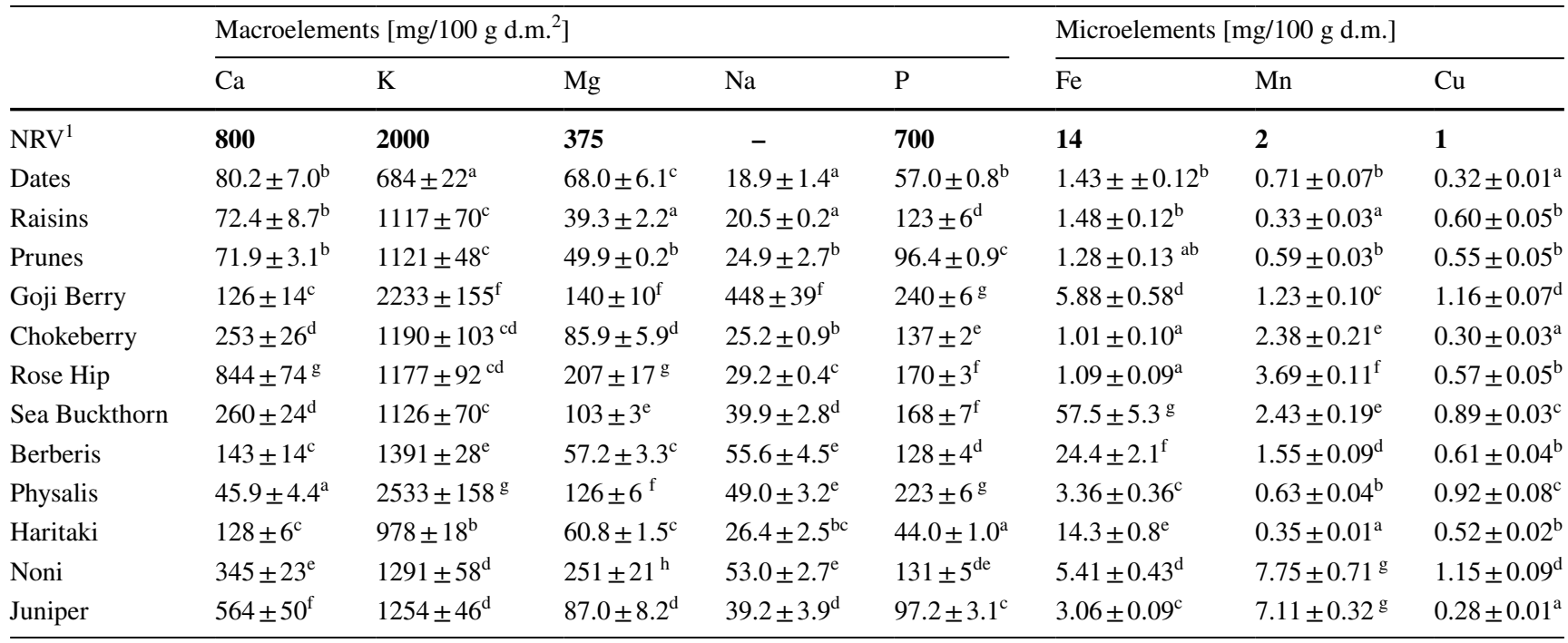

${ }^{1} N R V$ Nutrient Reference Value

${ }^{2}$ d.m. dry matter

Two determinations for each digest were performed (six replicates for one dried fruit), Mean values with the same letter in each column were not significantly different at $\alpha=0.05$ (sorted from the lowest to highest values)

variation in IDF content in dried fruits was found, ranging from 3.6 (raisins) to $49.0 \mathrm{~g} / 100 \mathrm{~g}$ (noni). Rose hip had slightly lower IDF content $(44.3 \mathrm{~g} / 100 \mathrm{~g})$ than noni, but it also had the highest content of SDF (12.0 g/100 g) among other dried fruits (0.6-4.9 g/100 g of SDF). Literature data suggest that the consumption of dried fruits rich in IDF (e.g., noni and rose hip) may be considered as an advantage due to increased satiety and intestinal regulation, while the beneficial effect of dietary intake of SDF (e.g., rose hip) results mainly from decreasing the rate of nutrients absorption and prevention of obesity and other metabolic disorders $[24,25]$. Therefore, the consumption of most of the dried 
Table 5 The antioxidant capacity expressed as the TP (total phenolic) and TF (total flavonoids) content, FRAP and TEAC values of dried fruits

\begin{tabular}{lcccc}
\hline & TP $\left[\mathrm{mg} / 100 \mathrm{~g} \mathrm{~d} . \mathrm{m}^{1}\right]$ & TF $[\mathrm{mg} / 100 \mathrm{~g} \mathrm{~d} . \mathrm{m}]$. & $\begin{array}{l}\text { FRAP } \\
{[\mathrm{mmol} / 100 \mathrm{~g}} \\
\text { d.m. }]\end{array}$ & $\begin{array}{c}\text { TEAC } \\
{[\mathrm{mmol} / 100 \mathrm{~g}} \\
\text { d.m. }]\end{array}$ \\
\hline Dates & & & $14.0 \pm 0.4^{\mathrm{e}}$ & $15.0 \pm 0.4^{\mathrm{e}}$ \\
Raisins & $1583 \pm 195^{\mathrm{e}}$ & $375 \pm 10^{\mathrm{c}}$ & $19.2 \pm 1.7^{\mathrm{f}}$ & $19.8 \pm 1.2^{\mathrm{f}}$ \\
Prunes & $1928 \pm 84^{\mathrm{f}}$ & $651 \pm 16^{\mathrm{d}}$ & $18.9 \pm 0.1^{\mathrm{f}}$ & $20.1 \pm 0.1^{\mathrm{f}}$ \\
Goji Berry & $2211 \pm 24^{\mathrm{f}}$ & $923 \pm 19^{\mathrm{f}}$ & $30.2 \pm 1.3^{\mathrm{g}}$ & $33.9 \pm 0.6^{\mathrm{h}}$ \\
Chokeberry & $3012 \pm 84^{\mathrm{g}}$ & $1009 \pm 8^{\mathrm{g}}$ & $11.6 \pm 0.1^{\mathrm{d}}$ & $10.8 \pm 0.4^{\mathrm{d}}$ \\
Rose Hip & $1139 \pm 17^{\mathrm{d}}$ & $775 \pm 40^{\mathrm{e}}$ & $42.1 \pm 2.5^{\mathrm{h}}$ & $35.4 \pm 3.0^{\mathrm{h}}$ \\
Sea Buckthorn & $3097 \pm 98^{\mathrm{g}}$ & $1845 \pm 80^{\mathrm{i}}$ & $5.34 \pm 0.36^{\mathrm{b}}$ & $3.64 \pm 0.25^{\mathrm{a}}$ \\
Berberis & $514 \pm 21^{\mathrm{a}}$ & $270 \pm 11^{\mathrm{b}}$ & $55.0 \pm 1.0^{\mathrm{i}}$ & $47.5 \pm 1.0^{\mathrm{i}}$ \\
Physalis & $6032 \pm 21^{\mathrm{h}}$ & $3897 \pm 160^{\mathrm{j}}$ & $28.0 \pm 0.7^{\mathrm{g}}$ & $28.7 \pm 0.6^{\mathrm{g}}$ \\
Haritaki & $3039 \pm 194^{\mathrm{g}}$ & $1325 \pm 32^{\mathrm{h}}$ & $207.2 \pm 4.7^{\mathrm{j}}$ & $481.2 \pm 4.7^{\mathrm{j}}$ \\
Noni & $32,612 \pm 169^{\mathrm{i}}$ & $3594 \pm 199^{\mathrm{j}}$ & $4.18 \pm 0.09^{\mathrm{a}}$ & $4.97 \pm 0.13^{\mathrm{b}}$ \\
Juniper & $657 \pm 55^{\mathrm{b}}$ & $218 \pm 14^{\mathrm{a}}$ & $6.82 \pm 0.74^{\mathrm{c}}$ & $7.51 \pm 0.75^{\mathrm{c}}$ \\
\hline
\end{tabular}

${ }^{1}$ d.m. dry matter

At least four determinations were performed for each extract of fruit (eight replicates for each dried fruit); Mean values with the same letter in each column were not significantly different at $\alpha=0.05$ (sorted from the lowest to highest values) fruits analyzed will be beneficial for healthy individuals but should be restricted by people on an easily digestible diet or suffering from disorders such as diarrhea or Irritative Bowel Syndrome [26].

Although the consumption of dietary fiber provides beneficial effects for healthy individuals such as reducing blood glucose or cholesterol [19], dietary fiber and tannins (Table 3) can interact with minerals lowering their bioavailability [12]. The content of minerals as well their recommended daily allowances, established at the level of Nutrient Reference Values (NRVs), were presented in Table 4. From the nutritional point of view especially important are potassium $(\mathrm{K})$, calcium $(\mathrm{Ca})$, magnesium $(\mathrm{Mg})$ and iron $(\mathrm{Fe})$. These minerals are often deficient in different groups, e.g., iron in vegans, calcium in osteoporosis, potassium, and magnesium in physically active people or people on a gluten-free diet. High/very high content of potassium was found in most of the analyzed dried fruits (excluding dates and haritaki). Very high content of calcium was found in noni $(345 \pm 23 \mathrm{mg} / 100 \mathrm{~g})$, juniper $(564 \pm 50 \mathrm{mg} / 100 \mathrm{~g})$ and rose hip $(844 \pm 74 \mathrm{mg} / 100 \mathrm{~g})$. As one portion of dried fruits should suit one hand, which corresponds to approximately $20 \mathrm{~g}$ of fruit [4], the portion of these products would cover up to $21 \%$ of NRV for this nutrient. Rose hip and noni were also rich in magnesium delivering $207 \mathrm{mg} / 100 \mathrm{~g}$ and $251 \mathrm{mg} / 100 \mathrm{~g}$, which corresponded to up to $13 \%$ of NRV for $\mathrm{Mg}$ in $20 \mathrm{~g}$ portion. A valuable source of magnesium were Goji berry and physalis, which had 126-140 mg of $\mathrm{Mg}$ in $100 \mathrm{~g}$. The content of minerals in Goji berry under the present study was comparable to its mineral composition published by Bertoldi and co-authors [27] who compared Italian and Asian Goji berries. The content of magnesium in seven Italian samples ranged from 72 to $267 \mathrm{mg} / 100 \mathrm{~g}$, while in sixteen Asian samples was slightly lower -78 to $161 \mathrm{mg} / 100 \mathrm{~g}$. The content of iron $(\mathrm{Fe})$ in products analyzed was in a wide range of $1 \mathrm{mg}$ (chokeberry) and $58 \mathrm{mg}$ in $100 \mathrm{~g}$ (sea buckthorn). Sea buckthorn had also the lowest content of tannins (only $0.27 \mathrm{mmol} \mathrm{TA} / 100 \mathrm{~g} \mathrm{~d}$.m.) and moderate content of TDF ( $35 \mathrm{~g} / 100 \mathrm{~g})$ which can further improve iron availability. Rich in iron were also berberis $(24.4 \mathrm{mg} / 100 \mathrm{~g})$ and haritaki $(14.3 \mathrm{mg} / 100 \mathrm{~g})$. The portion of these fruits could realize from 20 to $83 \%$ of NRV for $\mathrm{Fe}$, but, as mentioned above, the high content of antinutrients such as dietary fiber and tannins found in haritaki (33\% of TDF, $11.0 \mathrm{mmol} \mathrm{TA} / 100 \mathrm{~g}$ d.m.), rose hip (56\% of TDF, $3.2 \mathrm{mmol}$ TA/100 g d.m.) and noni (53\% of TDF) can limit the bioavailability of minerals. It must be emphasized that haritaki and noni were more like nuts than dried fruits therefore only as a powder are suitable for use in food formulations.

The antioxidant capacity of fruits expressed as the TP and TF contents, the TEAC and FRAP values were presented in Table 5. Haritaki was characterized by the highest content of TP and TF as well as the FRAP and TEAC values: 32,612 mg GAE/100 g d.m., 3594 mg CE/100 g d.m., $207.2 \mathrm{mmol} \mathrm{Fe}{ }^{2+} / 100 \mathrm{~g} \mathrm{~d} . \mathrm{m}$. and $481.2 \mathrm{mmol}$ Trolox/100 g d.m., respectively, followed by berberis $(6032 \mathrm{mg}$ GAE/100 g d.m., 3897 mg CE/100 g d.m., $55.0 \mathrm{mmol}$ $\mathrm{Fe}^{2+} / 100 \mathrm{~g}$ d.m. and $47.5 \mathrm{mmol}$ Trolox/100 g d.m.), rose hip (3097 mg GAE/100 g d.m., 1845 mg CE/100 g d.m., $42.1 \mathrm{mmol} \mathrm{Fe} \mathrm{F}^{2+} / 100 \mathrm{~g}$ d.m. and $35.4 \mathrm{mmol}$ Trolox/100 g d.m.) and Goji berry (3012 mg GAE/100 g d.m., $1009 \mathrm{mg}$ $\mathrm{CE} / 100 \mathrm{~g}$ d.m., $30.2 \mathrm{mmol} \mathrm{Fe} \mathrm{F}^{2+} / 100 \mathrm{~g}$ d.m. and $33.9 \mathrm{mmol}$ Trolox/100 g d.m.). Much lower content of TF than TP in 
haritaki was reported by Saha and Verma [28]. Comparison of the results obtained with literature data is difficult due to the application of different extraction solvents and conditions or standards to express TP and TF contents presented for dried fruits by various researchers. However, comparable content of TP, based on water extraction of polyphenols, was reported by Nadpal et al. [29] for rose hip (61.0 mg GAE/g d.m.) and by Chalise et al. [30] for haritaki (226.2 mg GAE/g d.m.). According to Ischiwata et al. [31] prunes and raisins, with their moderate amount of TP and antioxidant capacity, contain more TP and have higher DPPH scavenging activity than other popular dried fruits like apple and banana. In another study, conducted by Wu et al.[32], TP content in dried fruits decreased in the following order: prunes $\sim$ raisins $>$ dates, which is in line with our study. It is also worth emphasizing that dried fruits are a more valuable source of nutrients than their fresh counterparts although a loss or modification of phenolic compounds during the drying process can be also observed [33]. Moreover, our results demonstrated a high positive correlation between the TEAC and FRAP values and the content of TP and TF. The correlation coefficient between the TEAC value and the TP or TF were 0.964 and 0.877 , respectively. Slightly higher correlation coefficients were found for the FRAP value and the content of TP or TF ( 0.966 and 0.929 , respectively; $p<0.05$ ). These correlations were calculated excluding results obtained for haritaki due to the very high values of TEAC and FRAP differing significantly from the results obtained for other fruits.

Most of European FBDG suggest the consumption of two portions (200-300 g) of fresh fruits per day [4] and dried fruits are their attractive alternative. Some countries in their FBDG place dried fruits in the "grey zone" which means that they should be consumed occasionally and in limited quantities. For example, in Estonia it is suggested to eat no more than 2-3 servings ( $20 \mathrm{~g}$ per serving) a week while in France FBDG say that "dried fruit can count towards fruit consumption, yet their consumption is nevertheless to be limited and should not occur outside of meals". In Malta, FBDG recommends choosing fresh fruits over juice, dried and canned fruit which can constitute only one portion a day [4]. Undisputedly, dried fruit are an excellent alternative for unhealthy snacks such as chips or some cookies ("empty calories"). Dried fruits are an optimal, but not ideal, alternative to fresh fruits. In general, their nutritional value is similar to fresh fruits, though they are more concentrated and therefore they should be consumed in lower quantity than fresh fruits. Moreover, some dried fruits can contain significant amounts of sugar, fat or food preservatives such as salt or sulphur dioxide. Therefore their nutritional attractiveness is lower than fresh fruits but significantly higher than most of commercially available snacks. The daily consumption of dried fruits in the United Kingdom, which is no. 1 of importers of dried fruits in Europe (50\% of the import;
180,000 metric tons) is $11 \%$. The general UK population consumes approx. 5-6 $\mathrm{g}$ of dried fruits a day and it significantly differs among generations - young people eat $2 \mathrm{~g} /$ day, while $65+$ year-old eat $6 \mathrm{~g} / \mathrm{d}$ of dried fruits [34]. Also, the study conducted among Dutch, French, and Polish consumers showed that dried fruits themselves are eaten occasionally but products with the addition of dried fruits (e.g., oatmeal) are eaten more frequently [7]. From the nutritional and economical point of view, the most advantageous will be to consume them solely as healthy, handy, and affordable snacks, however, some of them (wild rose, haritaki, noni, juniper) require milling before being eaten. Moreover, in the case of unpopular dried fruits such as berberis, physalis, haritaki, noni or juniper the sensory analysis will be a crucial stage in their successful implementation to everyday menu.

For several dried fruits analyzed in this study, different implementations in food formulations have been lately published, and in case of e.g., Goji berry, chokeberry and sea buckthorn they apply to a variety of food products. Ducruet and co-authors [35] used Goji berry in the brewery and developed attractive beer with high content of antioxidants while Bora and co-authors [36] added Goji berry to cookies and muffins to enhance the nutritional and sensory properties. The studies for less popular fruits are very limited. In the case of noni, the studies apply to fermented noni juice which, to avoid the unpleasant smell, was encapsulated into powder [e.g., 38]. Pérez-Herrera and co-authors [38] developed jams with physalis. They found that jams with physalis seeds improved the nutritional quality, but seedless products represented greater sensory acceptance. An interesting form of dried fruits is also their powdered version. As mentioned by Shishir and Cher [39], powdered fruits and vegetables can be stored from months to years and their flexibility facilitates the preparation of advanced formulations and opens new markets. Moreover, for some samples under the study, especially for noni and haritaki, the powdering was crucial in the sample preparation. However, further complex studies on the e.g., in vitro digestion are necessary to complete their potential application in the food, pharmaceutical, and cosmetic industries.

\section{Conclusions}

Nutritionists recommend dried fruits as a healthy snack. In the study, twelve commercially available popular (dates, raisins, prunes) and less popular dried fruits (Goji berry, chokeberry, rose hip, sea buckthorn, berberis, physalis, haritaki, noni, juniper) were analyzed. Goji berry (13.3\%), sea buckthorn $(9.3 \%)$, noni $(8.9 \%)$ and physalis $(8.0 \%)$ can be regarded as a rich source of protein. A high content of fat was found in sea buckthorn $(11.2 \%)$, while high content of dietary fiber was found in most of analyzed products 
(4.4-53.0\%). Extremely high antioxidant capacity was noticed for haritaki, followed by berberis, physalis, rose hip and Goji berry. An important source of nutritionally important minerals, especially $\mathrm{Ca}, \mathrm{Mg}$, and $\mathrm{Fe}$, were: noni and rose hip $(\mathrm{Ca}$ and $\mathrm{Mg}$ ), juniper $(\mathrm{Ca})$, sea buckthorn, berberis and haritaki $(\mathrm{Fe})$. Further study on the implementation of nutritious dried fruits into food formulations is necessary, especially in relation to noni and haritaki, to limit the impact of antinutrient factors (dietary fiber and tannins) on the nutritional quality of the final product. Moreover, any activities, which will position dried fruits as a ready-to-eat daily snacks are highly recommended by nutritionists.

Data availability Not applicable.

Code availability Not applicable.

\section{Declarations}

Conflict of interest The authors declare no conflict of interest.

Ethical approval This article does not contain any studies with human or animal subjects.

Open Access This article is licensed under a Creative Commons Attribution 4.0 International License, which permits use, sharing, adaptation, distribution and reproduction in any medium or format, as long as you give appropriate credit to the original author(s) and the source, provide a link to the Creative Commons licence, and indicate if changes were made. The images or other third party material in this article are included in the article's Creative Commons licence, unless indicated otherwise in a credit line to the material. If material is not included in the article's Creative Commons licence and your intended use is not permitted by statutory regulation or exceeds the permitted use, you will need to obtain permission directly from the copyright holder. To view a copy of this licence, visit http://creativecommons.org/licenses/by/4.0/.

\section{References}

1. European Comission (2017). https://ec.europa.eu/jrc/en/healthknowledge-gateway/promotion-prevention/nutrition/fruit-veget ables. (Accessed 19 Oct 2020).

2. Krasteva DK, Kirilova RE (2014) Dried fruits - brief characteristics of their nutritional values Author's own data for dietary fibers content. J Food Nutr Sci. https://doi.org/10.11648/j.jfns. 20140204.12

3. Sullivan VK, Na M, Proctor DN, Kris-Etherton PM (2020) Consumption of dried fruits is associated with greater intakes of underconsumed nutrients, higher total energy intakes, and better diet quality in US adults: a cross-sectional analysis of the national health and nutrition examination survey, 2007-2016. J Acad Nutr Diet. https://doi.org/10.1016/j.jand.2020.08.085

4. EFSA, European Food Safety Authority (2010) Scientific opinion on establishing food-based dietary guidelines, EFSA Panel on Dietetic Products, Nutrition, and Allergies (NDA). https:// ec.europa.eu/jrc/en/health-knowledge-gateway/promotion-preve ntion/nutrition/food-based-dietary-guidelines. (Accessed $26 \mathrm{Mar}$ 2020).

5. Statista (2020). https://www.statista.com/topics/6002/dried-fruitmarket/. (Accessed 25 Oct 2020).

6. Altundag H, Tuzen M (2011) Comparison of dry, wet and microwave digestion methods for the multi element determination in some dried fruit samples by ICP-OES. Food Chem Tox. https:// doi.org/10.1016/j.fct.2011.07.064

7. Jesionkowska K, Sijtsema SJ, Simoneaux R, Konopacka D, Płocharski W (2008) Preferences and consumption of dried fruitand dried fruit products among dutch, french and polish consumers. J Fruit Orn Plant Res 16:261-274

8. Rose N, Reynolds T, Kolodinsky J (2020) Consumer use of food labels increases as "Clean Label" trend continues. J Nutr Educ Behav. https://doi.org/10.1016/j.jneb.2020.04.136

9. Montowska M, Kowalczewski PŁ, Rybicka I, Fornal E (2019) Nutritional value, protein and peptide composition of edible cricket powders. Food Chem. https://doi.org/10.1016/j.foodchem. 2019.03.06

10. Mohapatra D, Patel AS, Kar A, Deshpande SS, Tripathi MK (2019) Effect of different processing conditions on proximate composition, anti-oxidants, anti-nutrients and amino acid profile of grain sorghum. Food Chem. https://doi.org/10.1016/j.foodc hem.2018.07.196

11. Jeszka-Skowron M, Zgoła-Grześkowiak A, Stanisz E, Waśkiewicz A (2017) Potential health benefits and quality of dried fruits: Goji fruits, cranberries and raisins. Food Chem. https://doi.org/10. 1016/j.foodchem.2016.10.049

12. Kiewlicz J, Rybicka I (2020) Minerals and their bioavailability in relation to dietary fiber, phytates and tannins from gluten and gluten-free flakes. Food Chem. https://doi.org/10.1016/j.foodc hem.2019.125452

13. Murphy J, Riley JR (1962) A modified single solution method for the determination of phosphate in natural water. Anal Chim Acta. https://doi.org/10.1016/S0003-2670(00)88444-5

14. Singleton VL, Rossi JA (1965) Colorimetry of total phenolics with phosphomolybdic-phosphotungstic acid reagents. AM J Enol Viticult 16:144-158

15. Karadeniz F, Burdurlu HS, Koca N, Soyer Y (2017) Antioxidant activity of selected fruits and vegetables grown in Turkey. Turk $\mathrm{J}$ Agri For 29:297-303

16. Re R, Pellergini N, Proteggente A, Pannala AS, Yang M, RiceEvans C (1999) Antioxidant activity applying an improved ABTS radical cation decolorization assay. Free Rad Biol Med. https:// doi.org/10.1016/S0891-5849(98)00315-3

17. Enko J, Gliszczyńska-Świgło A (2015) Influence of the interactions between tea (Camellia sinensis) extracts and ascorbic acid on their antioxidant activity, analysis with interaction indexes and isobolograms. Food Add Cont. https://doi.org/10.1080/19440049. 2015.1049218

18. Benzie IFF, Strain JJ (1999) The ferric reducing ability of plasma (FRAP) as a measure of ,antioxidant power": the FRAP assay. Anal Biochem 239:70-76

19. Rodrigues RS, Cruz Caldas J, Lopes MV, Lopes dos Santos WS, Andrade Korn MG, de Freitas Santos Júnior A (2019) Multielementar/centesimal composition and determination of bioactive phenolics in dried fruits and capsules containing Goji berries (Lycium barbarum L). Food Chem. https://doi.org/10.1016/j.foodc hem.2018.05.124

20. Koskovac M, Cupara S, Kipic M, Barjaktarevic A, Milovanovic O, Kojicic K, Markovic M (2017) Sea buckthorn oil-A valuable source for cosmeceuticals. Cosmetics. https://doi.org/10.3390/ cosmetics 4040040

21. USDA, USDA national nutrient database for standard reference (2019) https://fdc.nal.usda.gov/. (Accessed 20 Sept 2020). 
22. Anderson JW, Waters AR (2013) Raisin consumption by humans: effects on glycemia and insulinemia and cardiovascular risk factors. J Food Sci. https://doi.org/10.1111/1750-3841.12071

23. Jeong O, Kim HS (2019) Dietary chokeberry and dried jujube fruit attenuates high-fat and high-fructose diet induced dyslipidemia and insulin resistance via activation of the IRS-1/PI3K/Akt pathway in C57BL/6 J mice. Nutr Metab. https://doi.org/10.1186/ s12986-019-0364-5

24. Vega-Gálvez A, Zura-Bravo L, Lemus-Mondaca R, MartinezMonzó J, Quispe-Fuentes I, Puente L, Di Scala K (2015) Influence of drying temperature on dietary fibre, rehydration properties, texture and microstructure of Cape gooseberry (Physalis peruviana L.). J Food Sci Tech. https://doi.org/10.1007/s13197-013-1235-0

25. Cavalera M, Axling U, Berger K, Holm C (2016) Rose hip supplementation increases energy expenditure and induces browning of white adipose tissue. Nutr Metab. https://doi.org/10.1186/ s12986-016-0151-5

26. McRorie JW Jr (2019) The physics of fiber in the gastrointestinal tract: laxation, antidiarrheal, and irritable bowel syndrome. In: Watson RR, Preedy VR (eds) Dietary Interventions in gastrointestinal diseases foods, nutrients, and dietary supplements. Elsevier Inc

27. Bertoldi D, Lina Cossignani Blasi F, Perini M, Barbero A, Pianezze S, Montesano D (2019) Characterisation and geographical traceability of Italian Goji berries. Food Chem. https://doi.org/10. 1016/j.foodchem.2018.09.098

28. Saha S, Verma RJ (2016) Antioxidant activity of polyphenolic extract of Terminalia chebula Retzius fruits. J Taibah Uni Sci. https://doi.org/10.1016/j.jtusci.2014.09.003

29. Nadpal JD, Lesjak MM, Śibul FS, Anackov GT, Cetojevic-Simin D, Mimica-Dukic NM, Beara IN (2016) Comparative study of biological activities and phytochemical composition of two rose hips and their preserves: Rosa canina L. and Rosa arvensis Huds. Food Chem. https://doi.org/10.1016/j.foodchem.2015.07.089

30. Chalise JP, Acharya K, Gurung N, Bhusal RP, Gurung R, SkalkoBasnet N, Basnet P (2010) Antioxidant activity and polyphenol content in edible wild fruits from Nepal. Int J Food Sci Nutr. https://doi.org/10.3109/09637481003591590

31. Ishiwata K, Yamaguchi T, Takamura H, Matoba T (2004) DPPH radical-scavenging activity and polyphenol content in dried fruits. Food Sci Tech Res. https://doi.org/10.3109/09637481003591590
32. Wu X, Beecher GR, Holden JM, Haytowitz DB, Gebhardt SE, Prio RL (2004) Lipophilic and hydrophilic antioxidant capacities of common foods in the United States. J Agri Food Chem. https:// doi.org/10.1021/jf049696w

33. Donno D, Mellano MG, Raimondo E, Cerutti AK, Prgomet Z, Beccaro GL (2016) Influence of applied drying methods on phytochemical composition in fresh and dried goji fruits by HPLC fingerprint. Eur Food Res Tech. https://doi.org/10.1007/ s00217-016-2695-z

34. Sadler MJ, Gibson S, Whelan K, Ha MA, Lovegrove J, Higgs J (2019) Dried fruit and public health - what does the evidence tell us? Int J Food Sci Hum Nutr. https://doi.org/10.1080/09637486. 2019.1568398

35. Ducruet J, Rébénaque P, Diserens S, Kosińska-Cagnazzo A, Héritier I, Andlauer W (2019) Amber ale beer enriched with Goji berries - The effect on bioactive compound content and sensorial properties. Food Chem. https://doi.org/10.1016/j.foodchem.2017. 01.047

36. Bora P, Ragaee S, Abdel-AAl SM (2019) Effect of incorporation of Goji berry by-product on biochemical, physical and sensory properties of selected bakery products. LWT Food Sci Tech. https://doi.org/10.1016/J.LWT.2019.05.123

37. Zhang C, Ada SL, Chen XD, Quek SY (2020) Microencapsulation of fermented noni juice via micro-fluidic-jet spray drying: evaluation of powder properties and functionalities. Powder Tech. https://doi.org/10.1016/j.powtec.2019.10.098

38. Pérez-Herrera A, Martínez-Gutiérrez GA, León-Martínez FM, Sánchez-Medina MA (2020) The effect of the presence of seeds on the nutraceutical, sensory and rheological properties of Physalis spp fruits jam: a comparative analysis. Food Chem. https://doi. org/10.1016/j.foodchem.2019.125141

39. Shishir MRI, Chen W (2017) Trends of spray drying: a critical review on drying of fruit and vegetable juices. Trends Food Sci Tech. https://doi.org/10.1016/j.tifs.2017.05.006

Publisher's Note Springer Nature remains neutral with regard to jurisdictional claims in published maps and institutional affiliations. 